Geology, Geophysics \& Environment • 2012 • Vol. 38 • No. 2 • 263-272

http://dx.doi.org/10.7494/geol.2012.38.2.263

\title{
ZLOŻA EWAPORATOWE TURCJI - BORANY, SIARCZANY, CHLORKI
}

\section{Evaporite deposits in Turkey - borates, sulphates, chlorides}

\author{
Katarzyna POBORSKA-MLYNARSKA ${ }^{1}$ \\ \& Hanna TOMASSI-MORAWIEC ${ }^{2}$
}

\author{
${ }^{1}$ AGH Akademia Górniczo-Hutnicza, Wydziat Górnictwa i Geoinżynierii; \\ al. A. Mickiewicza 30,30-059 Kraków; e-mail: kpm@agh.edu.pl \\ ${ }^{2}$ Państwowy Instytut Geologiczny-Państwowy Instytut Badawczy; \\ ul. Rakowiecka 4, 00-975 Warszawa; \\ e-mail: hanna.tomassi-morawiec@pgi.gov.pl
}

\begin{abstract}
Treść: Słone jeziora oraz złoża ewaporatów jezior słonych w Turcji są ważnym źródłem chemicznych surowców mineralnych. Pozyskuje się z nich głównie: borany, węglany sodu, siarczany sodu oraz sól (chlorek sodu). Jeziora słone płaskowyżu anatolijskiego są zróżnicowane pod względem chemizmu wód i warunków ewaporacji. Również neogeńskie (trzeciorzędowe) złoża ewaporatów jezior słonych w tym regionie charakteryzują się specyficznym, często unikatowym składem mineralnym. Zapoznanie się $\mathrm{z}$ warunkami ewaporacji i sedymentacji w słonych jeziorach oraz $\mathrm{z}$ budową geologiczną i eksploatacją złóż ewaporacyjnych jezior słonych było celem geologiczno-górniczego seminarium Polskiego Stowarzyszenia Górnictwa Solnego (PSGS), które odbyło się w Turcji w dniach od 7 do 14 września. Na trasie wyprawy znalazły się: słone jeziora Salda i Tuz, złoże i kopalnia boranów Kirka oraz złoże i kopalnia siarczanów sodu Çayirhan. Podczas seminarium odwiedzono również: miejscowość Pamukkale z gorącymi źródłami, z których krystalizują trawertyny, złoża znanych od czasów starożytnych marmurów w rejonie Iscehisar - Afyon oraz płaskowyż Kapadocji ze słynnymi formami erozji i wietrzenia.
\end{abstract}

Słowa kluczowe: wyprawa naukowa PSGS, Turcja, jeziora słone, złoża boranów, siarczany sodu

\begin{abstract}
In Turkey, salt lakes and lacustrine evaporite deposits are an important source of industrial minerals such as: borates, soda ash, sodium sulphates and salt (sodium chloride). In the Anatolian Plateau salt lakes differ in the chemical composition of body waters and evaporation conditions as well as tertiary lacustrine evaporitic deposits with its specific and often unique mineralogical composition. The review of conditions of evaporation and precipitation in salt lakes and lacustrine evaporite deposits geology and method of exploitation were the goals of the scientific expedition of Polish Salt Mining Association (PSMA) in Turkey which took place from 7th to 14th September 2011. The route lead through Anatolian Plateau to the salt lakes: Salda and Tuz, to the Kirka borates deposit and Çayirhan sodium sulphates deposit. During the expedition were visited also other places: Pamukkale - with hot springs and travertine precipitation, the marble deposits in the Iscehisar - Afyon region known since ancient times and Cappadocia vulcanic plateau with famous forms of weathering and erosion.
\end{abstract}

Key words: scientific expedition PSMA, Turkey, salt lakes, borates deposits, sodium sulphate deposits 


\section{WPROWADZENIE}

Ewaporaty jezior słonych występują stosunkowo rzadko w skałach osadowych skorupy ziemskiej i eksploatowane są w niewielu miejscach na świecie. Turcja jest jednym z obszarów występowania na świecie jezior słonych ze współczesnymi osadami ewaporacyjnymi oraz neogeńskich (trzeciorzędowych) złóż ewaporatów jezior słonych, z których pozyskiwane są: borany, węglany sodu, siarczany sodu oraz sól (chlorek sodu). Wydobywa się tu około $4.4 \mathrm{mln}$ ton rudy boranowej rocznie (największa produkcja związków boru na świecie), 2 mln ton węglanów sodu, $5 \mathrm{mln}$ ton koncentratów siarczanu sodu oraz wytwarza $4 \mathrm{mln}$ ton soli (chlorku sodu) (USGS 2010 Minerals Yearbook). Zapoznanie się z warunkami geologicznymi tworzenia ewaporatów jeziornych, z budową geologiczną złóż oraz technologią i warunkami eksploatacji było przedmiotem i celem geologiczno-górniczego seminarium Polskiego Stowarzyszenia Górnictwa Solnego, które odbyło się w dniach od 7 do 14 września 2011 r. Trasa wyprawy wiodła z południowego wybrzeża Turcji (Fig. 1), poprzez góry Taurus na płaskowyż Anatolii południowo-zachodniej, gdzie prowadziła nad jezioro słone Salda, następnie do Pamukkale - ze słynnymi trawertynami powstającymi z wód gorących źródeł, dalej na północ - poprzez znane złoża marmuru w rejonie Iscehisar - Afyon do kopalni boranów Kirka, a następnie do najbardziej na północ wysuniętego miejsca wyprawy - kopalni siarczanów sodu Çayirhan w rejonie Beypazari. Stąd rozpoczął się powrót ku południowemu wybrzeżu: nad jezioro słone Tuz w środkowej Anatolii, dalej ku południowemu wschodowi do krainy Kapadocji, słynnej z niezwykłych form wietrzenia skał, a następnie poprzez miejscowość Konya i góry Taurus na wybrzeże Morza Egejskiego w okolice miejscowości Alanya i Antalya. Trasa wyprawy utworzyła pętlę o długości 1900 km.

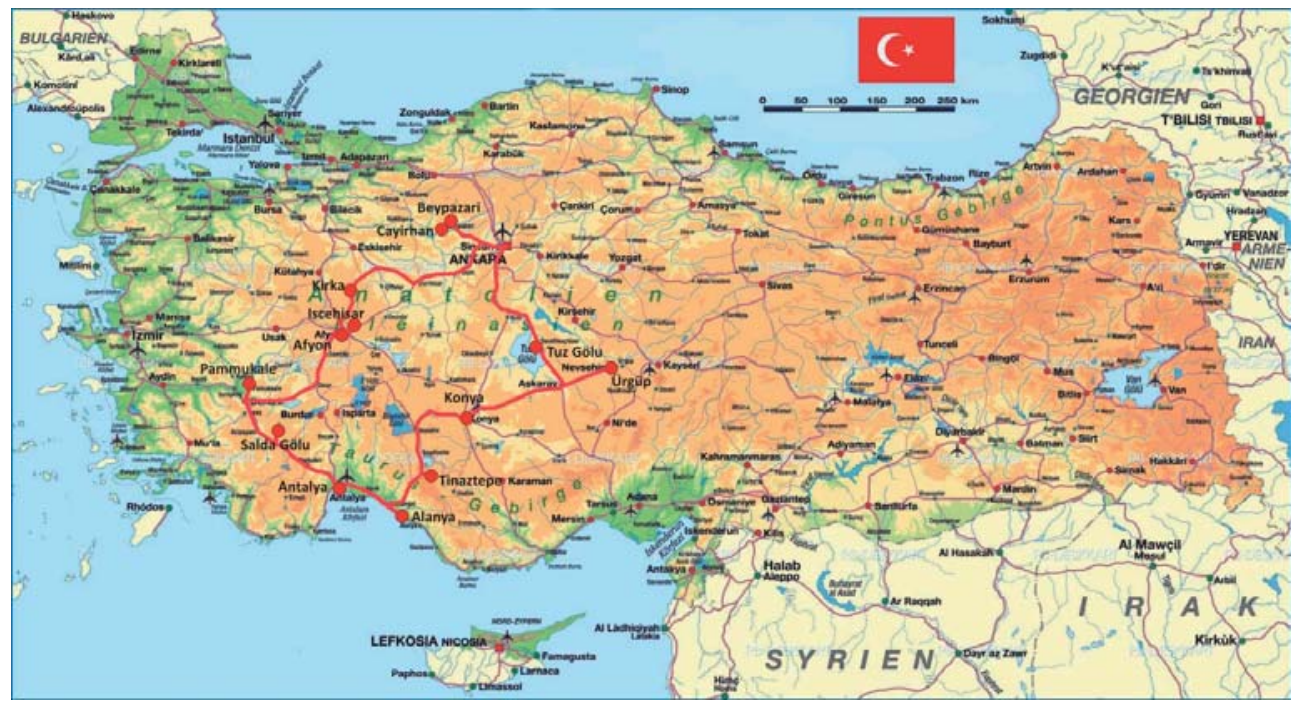

Fig. 1. Seminarium geologiczno-górnicze PSGS w Turcji - trasa przejazdu

Fig. 1. The rout of the PSMA geology and mining seminar expedition in Turkey 
Opis najważniejszych zwiedzanych miejsc: złóż surowców, kopalń, słonych jezior i innych obiektów geologicznych przedstawiono w artykule. W wyprawie uczestniczyli członkowie i sympatycy Stowarzyszenia. Na całej trasie w zwiedzanych kopalniach uczestnicy seminarium spotkali się z życzliwością i gościnnością gospodarzy, co umożliwiło osiągnięcie celów wyprawy.

\section{SLONE JEZIORA}

\section{Jezioro Salda (Salda Gölu)}

W południowo-zachodniej Turcji znajdują się jeziora słono- i słodkowodne, będące pozostałością jeziora lub systemu jezior powstałych w plejstocenie (Kazanci et al. 2004 ). Jednym z nich jest jezioro Salda (Fig. 2). Leży ono na wysokości 1180 m n.p.m., ma powierzchnię $45 \mathrm{~km}^{2}$, a jego głębokość sięga miejscami 180-200 m. Jezioro jest bezodpływowe, zasilane kilkoma strumieniami. Wody jeziora są wysokoalkaliczne sodowe ( $\mathrm{pH} 8-10)$, bogate w magnez (300 ppm.). Zagłębienie, w którym leży jezioro, wraz z górzystym otoczeniem tworzy basen drenażu dla wód opadowych spływających poprzez ultrazasadowe i węglanowe skały, wskutek czego wody jeziora są wzbogacane w sód, magnez i węglany.

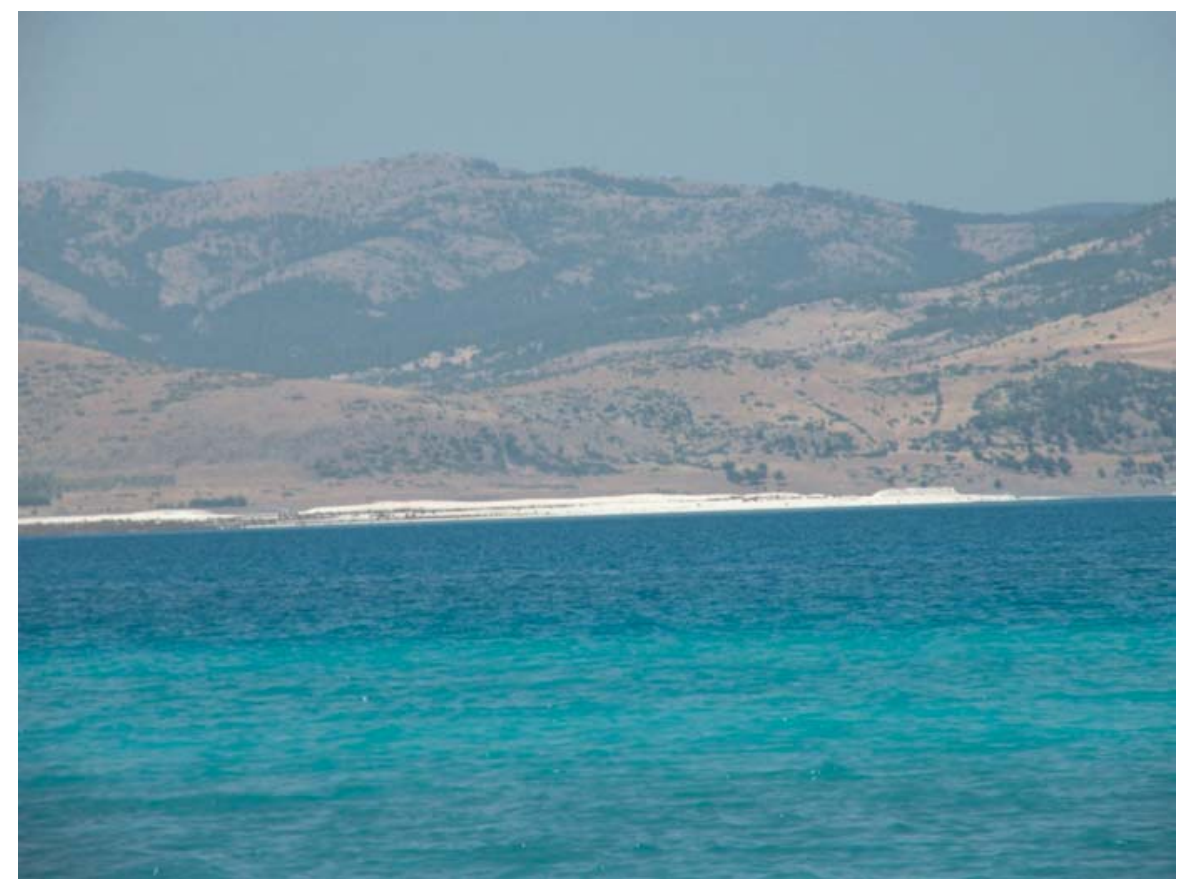

Fig. 2. Słone jezioro Salda (fot. W. Andrusikiewicz)

Fig. 2. Salt Lake Salda (phot. W. Andrusikiewicz) 
Osobliwością i wyjątkowo rzadkim zjawiskiem, jakie zachodzi w wodach jeziora, jest wytrącanie się i osadzanie hydromagnezytu $\mathrm{Mg}_{5}\left(\mathrm{CO}_{3}\right)_{4}(\mathrm{OH})_{2} \cdot 4 \mathrm{H}_{2} \mathrm{O}$, uwarunkowane nie tylko dużą zawartością jonów magnezu, ale procesami organicznymi: w jeziorze wzdłuż jego linii brzegowej tworzą się stromatolity, których głównym składnikiem jest hydromagnezyt. Rozkruszony na skutek działalności wód hydromagnezyt gromadzi się na żwirowatych terasach otaczających jezioro.

\section{Jezioro Tuz (Tuz Gölu)}

Basen słonego jeziora Tuz (Fig. 3) leży w środkowej Anatolii i zajmuje 16000 km² (Kýlýc \& Kýlýc 2005 ). Stanowi on zespól typu ,playa-lake” otoczony wyżynami. Jest to pozostałość po rozległym śródlądowym jeziorze, które pokrywało pomiędzy 23 tys., a 17 tys. lat temu basen Konya. Jezioro Tuz zajmujące obecnie powierzchnię około $1600 \mathrm{~km}^{2}$ zasilane jest przez trzy rzeki i kilka okresowych strumieni. Jego główna część zachodnia jest płytszana wiosnę głębokość wód dochodzi do $0.7 \mathrm{~m}$, ale potem jezioro wysycha. W części wschodniej, głębszej, wody o głębokości powyżej $1 \mathrm{~m}$ na wiosnę utrzymują się cały rok. Jezioro jest alkaliczne (pH 7-8), jednakże jego chemizm zmienia się w różnych strefach. W jego wodach występują jony: $\mathrm{Na}, \mathrm{Ca}, \mathrm{Mg}$, K, siarczanowe i chlorkowe. Ponad połowa zapotrzebowania na sól w Turcji zaspokajana jest solą produkowaną w panwiach solnych na obrzeżach jeziora.

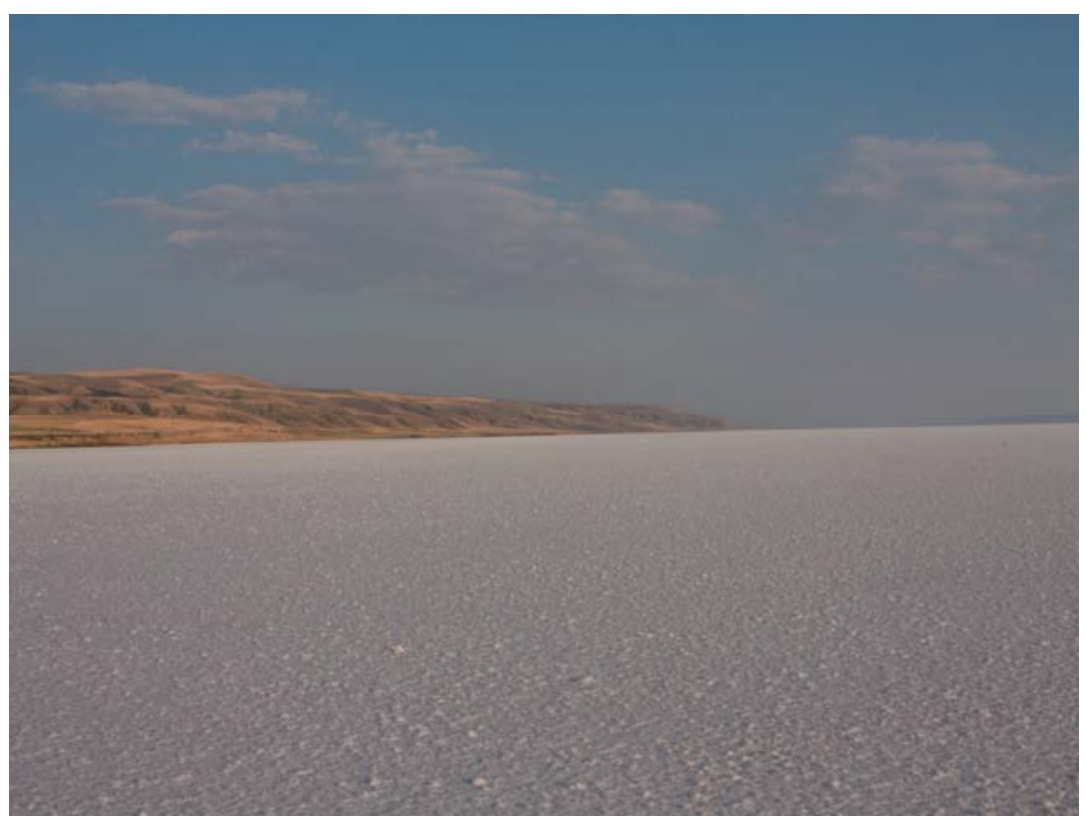

Fig. 3. Słone jezioro Tuz (fot. W. Andrusikiewicz)

Fig. 3. Salt Lake Tuz (phot. W. Andrusikiewicz) 


\section{ZŁOŻA EWAPORATÓW JEZIOR SŁONYCH}

\section{Złoże boranów Kirka}

Obszar występowania złóż boranów w zachodniej Anatolii stanowi pas o długości 300 km w kierunku W-E i 150 km w kierunku N-S. Leżą tu złoża: Kirka, Emet, Kestelek, Bigadiç i Sultançayir, przy czym cztery pierwsze są eksploatowane (Helvaci \& Ortí 2004). Są to złoża mioceńskie powstałe jako osady okresowych słonych jezior. Wulkaniczno-sedymentacyjna sekwencja wypełniająca rozległy basen sedymentacyjny składa się ze skał wulkanicznych, dwóch serii boranowych, tufów i bazaltów. Spoczywa ona na podłożu zbudowanym z metamorficznych skał paleozoicznych, ofiolitów mezozoicznych i wapieni eocenu. Poszczególne złoża różnią się składem mineralogicznym: w złożu Bigadiç wydobywa się kolemanit $\left(\mathrm{CaB}_{3} \mathrm{O}_{4}(\mathrm{OH})_{3} \cdot \mathrm{H}_{2} \mathrm{O}\right)$ i uleksyt $\left(\mathrm{NaCaB}_{5} \mathrm{O}_{6}(\mathrm{OH})_{6} \cdot 5 \mathrm{H}_{2} \mathrm{O}\right)$, w złożu Kestelek i Emet - kolemanit, a w złożu Kirka - boraks (tinkal) $\left(\mathrm{Na}_{2} \mathrm{~B}_{4} \mathrm{O}_{5}(\mathrm{OH})_{4} \cdot 8 \mathrm{H}_{2} \mathrm{O}\right)$. Złoże boranów Kirka jest jednym z największych na świecie. Miąższość serii boranowej równa jest 70 m, a lokalnie osiąga 145 m. Grubość nadkładu sięga około 200 m. Wydobycie prowadzi się w kopalni odkrywkowej (Fig. 4). Głównymi minerałami złoża przemysłowego są: boraks, uleksyt i kolemanit. Zawartość $\mathrm{B}_{2} \mathrm{O}_{3}$ w złożu wynosi 20-25\%.

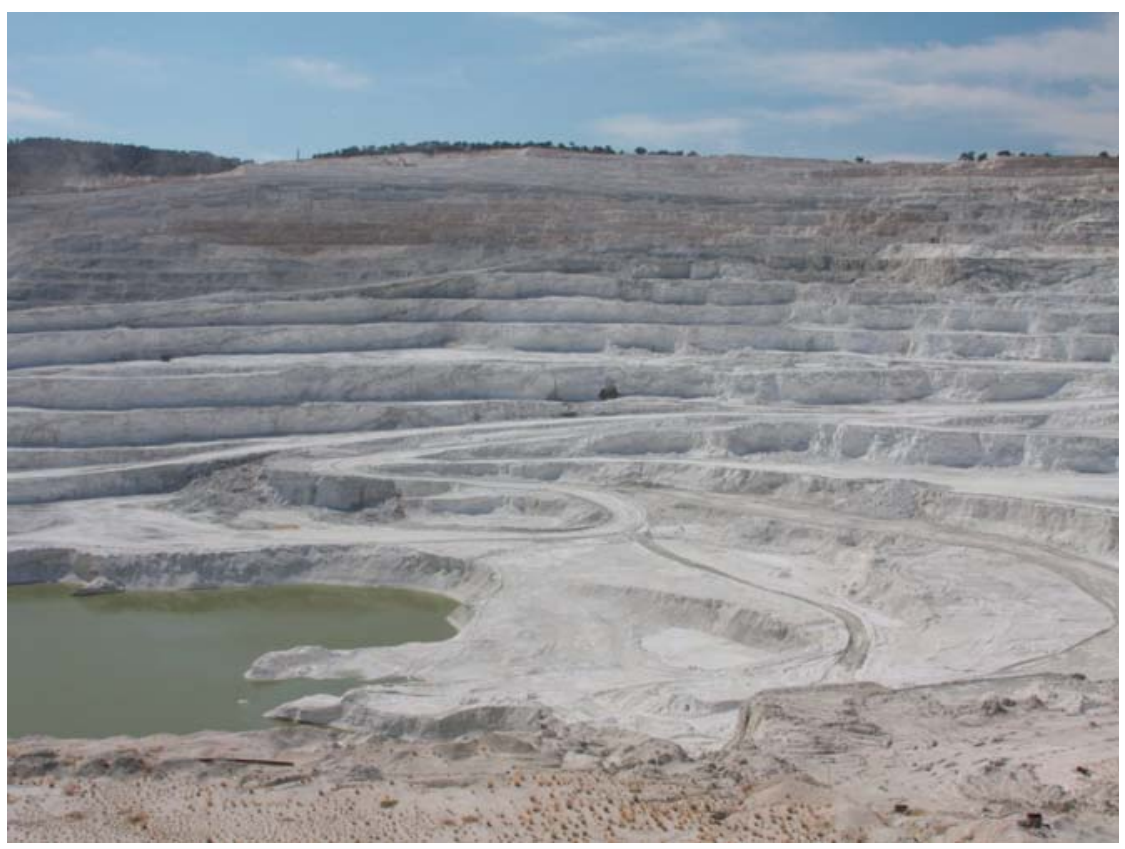

Fig. 4. Złoże boraksu Kirka (fot. W. Andrusikiewicz)

Fig. 4. Borax deposit, Kirka (phot. W. Andrusikiewicz) 


\section{Złoże siarczanów sodu Çayirhan w rejonie Beypazari}

Basen Beypazari leżący w środkowej Anatolii wypełnia formacja środkowego i górnego miocenu o miąższości 1200 m, składająca się z osadów klastycznych, ewaporatów, węglanów i kompleksów skał wulkanicznych (Ortí et al. 2002 ). Najmłodszą jej jednostką jest formacja Kirmir o miąższości 250 m, leżąca w środkowej części basenu. Utworzyła się w środowisku płytkowodnym jezior słonych. Składają się na nią człony: gipsowo-iłowcowy, ewaporatowy z siarczanami sodu i iłowcowy. Człon ewaporatowy o miąższości sięgającej do $100 \mathrm{~m}$ zbudowany jest z warstw glauberytu $\left(\mathrm{Na}_{2} \mathrm{SO}_{4} \cdot \mathrm{CaSO}_{4}\right)$, mirabilitu $\left(\mathrm{Na}_{2} \mathrm{SO}_{4} \cdot 10 \mathrm{H}_{2} \mathrm{O}\right)$ i tenardytu $\left(\mathrm{Na}_{2} \mathrm{SO}_{4}\right)$ - wydobywanych ze złoża Çayirhan. Eksploatacja prowadzona jest metodą ługowniczą w płytkiej kopalni podziemnej (Fig. 5).

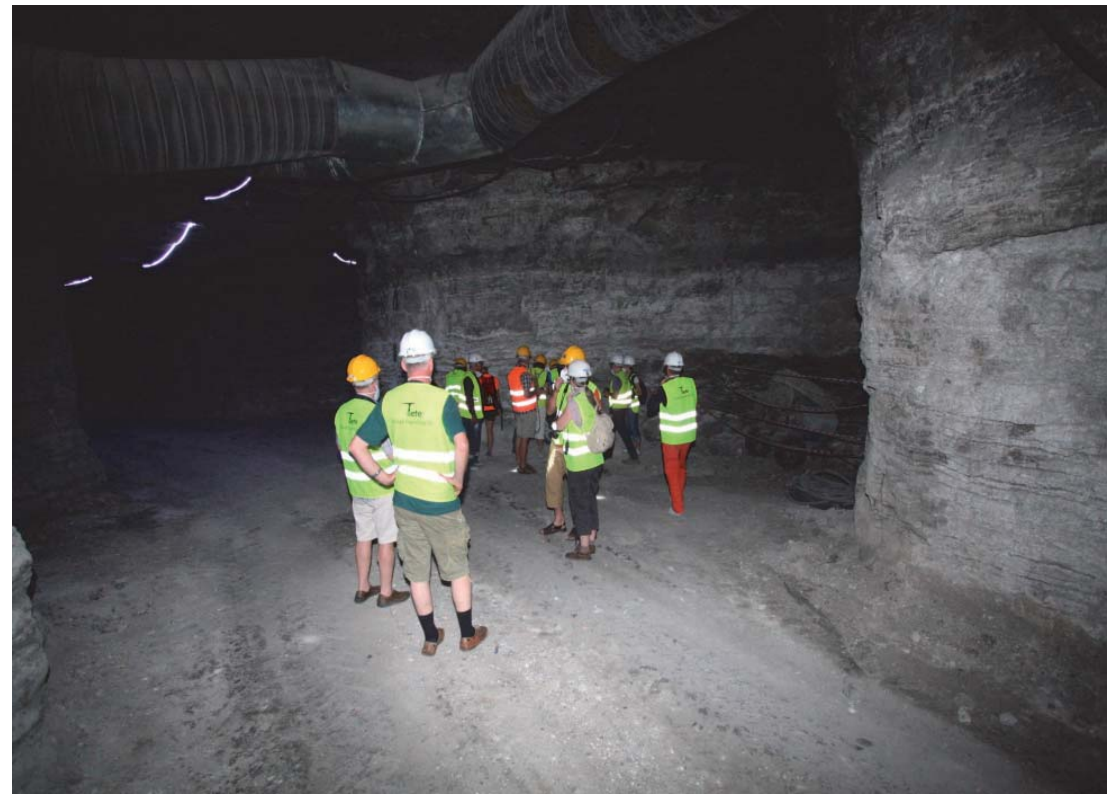

Fig. 5. Kopalnia siarczanów sodu Çayirhan (fot. W. Andrusikiewicz)

Fig. 5. Sodium sulphides mine, Çayirhan (phot. W. Andrusikiewicz)

\section{INNE STANOWISKA GEOLOGICZNE}

\section{Trawertyny Pamukkale}

Obszar hydrotermalny w miejscowości Pamukkale i jej okolicach, w zachodniej Anatolii, znany jest od czasów starożytnych z gorących źródeł $\left(35-56^{\circ} \mathrm{C}\right)$, z których krystalizują słynne śnieżnobiałe trawertyny (Fig. 6). Trawertyny tworzą się w kilku odmianach, zajmując 
powierzchnię około $10 \mathrm{~km}^{2}$. Powstają tu od przynajmniej 400000 lat i częściowo pokryły ruiny starożytnego frygijskiego miasta Hierapolis. System hydrotermalny Pamukkale tworzą wielowarstwowe połączone tektonicznie poziomy wodonośne w różnowiekowych skałach węglanowych, zasilane wodami opadowymi (Dilsiz et al. 2004). Podziemna migracja wód, gradient geotermiczny, rozpuszczanie węglanów, prawdopodobny kontakt z wodami hydrotermalnymi - stanowią mechanizm powstawania na tym obszarze gorących źródeł z wodami wzbogaconymi w jony wapnia, magnezu i węglanowe. Obszar, na którym powstają białe trawertyny w Pamukkale, objęty jest ochroną i figuruje na liście UNESCO Światowego Dziedzictwa Przyrodniczego.

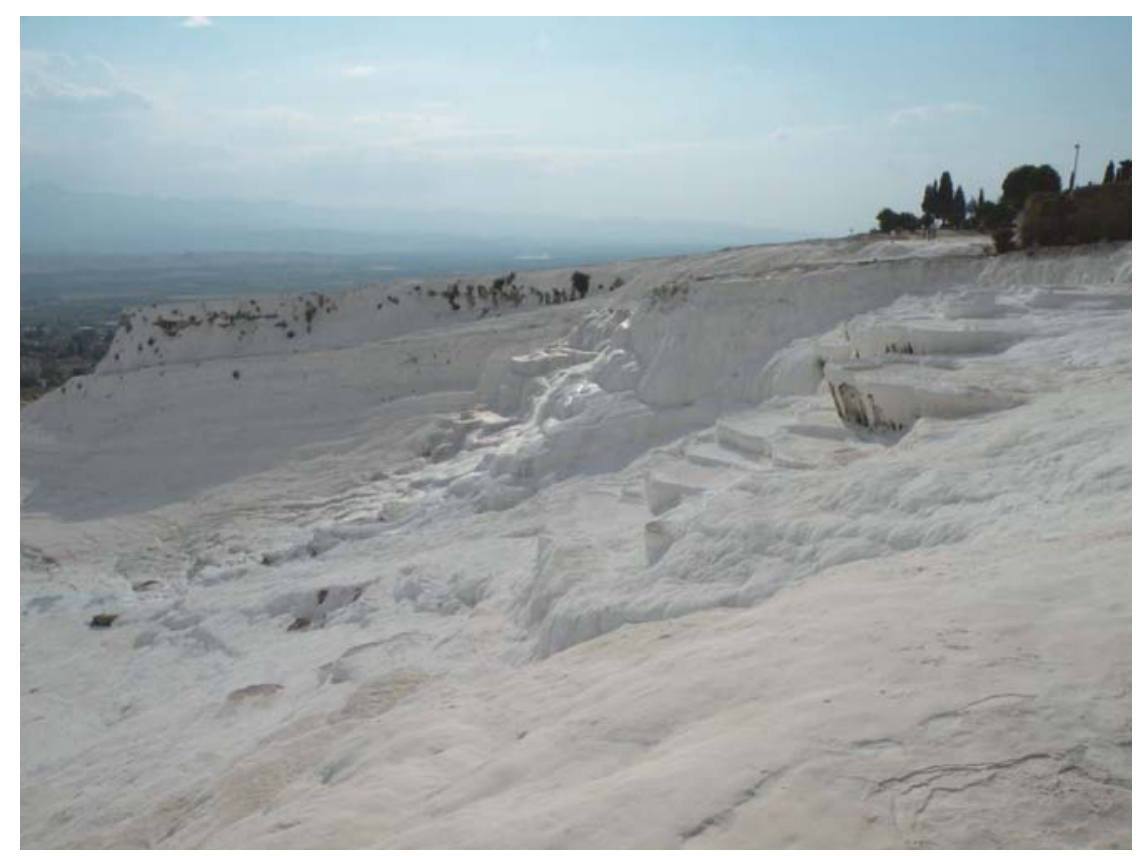

Fig. 6. Wytrącanie się trawertynu, Pamukkale (fot. W. Andrusikiewicz)

Fig. 6. Travertine precipitation, Pamukkale (phot. W. Andrusikiewicz)

\section{Zıża marmuru w rejonie Iscehisar - Afyon}

Na obszarze Turcji licznie występują złoża marmuru, z których wydobywa się ponad 250 ich rodzajów. Jednymi ze znanych w świecie są marmury regionu Iscehisar - Afyon, wydobywane już za czasów cesarstwa rzymskiego (Yavuz Celik \& Sabah 2008 ). Dwa eksploatowane złoża leżą około $25 \mathrm{~km}$ na NE od miasta Afyon. Występują w grubym kompleksie zmetamorfizowanych skał paleozoicznych w tzw. metamorfitach Afyonu. Marmury są białe, kremowe, zbudowane z drobnokrystalicznego kalcytu. Ze złóż wydobywa się kilka odmian 
marmuru o rynkowych nazwach: Afyon White, Afyon Sugar, Tigerskin i in. W prowincji Afyon znajduje się 3,5\% krajowych zasobów marmuru i wytwarza się tu 9\% produkcji marmuru w blokach (Fig. 7).

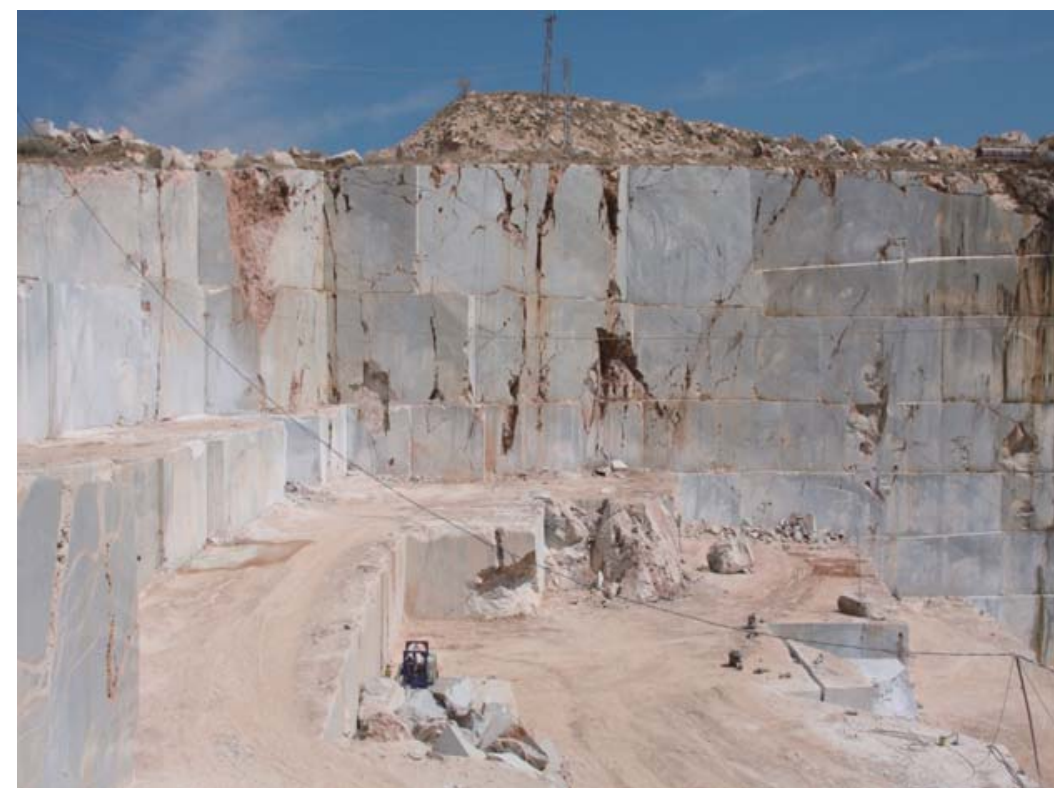

Fig. 7. Złoże marmuru w rejonie Iscehisar - Afyon (fot. W. Andrusikiewicz)

Fig. 7. Marble deposit, Iscehisar - Afyon region (phot. W. Andrusikiewicz)

\section{Kapadocja}

Kapadocja jest krainą znajdującą się w południowej części środkowej Anatolii na wschód od miasta Konya. Leży w strefie kolizji płyty anatolijskiej (fragmentu płyty euroazjatyckiej) z płytą afrykańską, skutkiem czego jest obszarem aktywnym tektonicznie (Zorlu et al. 2011). Na rozległych aktywnych strefach uskokowych rozbudowane są struktury młodych stratowulkanów (np. Erciyes Daği 3917 m n.p.m. i Hasan Daği 3268 m n.p.m.). Około 13 mln lat temu powstał tu płaskowyż przykryty formacją osadów wulkanogenicznych przewarstwioną osadami rzecznymi i jeziornymi. W obrębie formacji występuje kilkanaście odrębnych pokryw osadów wulkanicznych: ignimbrytów, tufów i potoków lawowych. Dzisiejszy niezwykły krajobraz Kapadocji jest efektem erozji i wietrzenia. Procesy te postępowały wzdłuż stref tektonicznych. Warstwy mniej odporne (mniej zwięzłe utwory piroklastyczne i osady jeziorne) szybciej w porównaniu z innymi skałami wulkanicznymi (np. lawami bazaltowymi) ulegały wietrzeniu i erozji. Skutkiem tego powstały niezwykłe, malownicze formy skalne: wąwozy, grzędy, baszty czy grzyby (Fig. 8). 

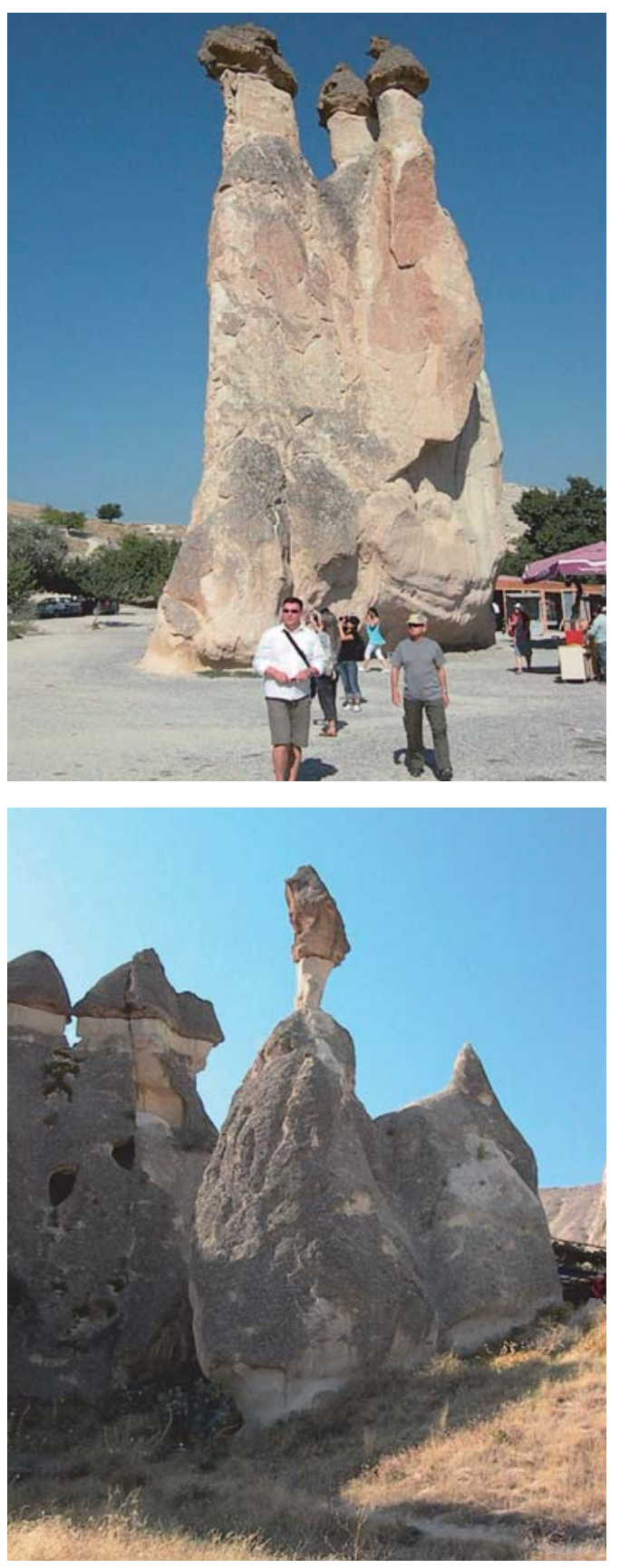

Fig. 8. Krajobraz Kapadocji (fot. W. Andrusikiewicz)

Fig. 8. Landscape of Cappadocia (phot. W. Andrusikiewicz) 


\section{LITERATURA}

Dilsiz C., Marquez J.M. \& Carreira P.M., 2004. The impact of hydrological changes on travertine deposits related to thermal springs in the Pamukkale area (SW Turkey). Environmental Geology, 45, 808-817.

Helvaci C. \& Ortí F., 2004. Zoning in the Kirka borate deposit, Western Turkey: primary evaporitic fractionation or diagenetic modifications? The Canadian Mineralogist, 42, 1179-1204.

Kazanci N., Girgin S. \& Dugel M., 2004. On the limnology of Salda Lake, a large and deep soda lake in southwestern Turkey: future management proposals. Aquatic Conservation: Marine and Fresh Water Ecosystems, 14, 151-162.

Kýlýc O. \& Kýlýc A.M., 2005. Recovery of salt co-products during the salt production from brine. Desalination, 186, 11-19.

Ortí F., Gündogan I. \& Helvaci C., 2002. Sodium sulphate deposits of Neogene age: the Kirmir Formation, Beypazari Basin, Turkey. Sedimentary Geology, 146, 305-333.

USGS 2010 Minerals Yearbook, www. minerals.usgs.gov/minerals/

Yavuz Celik M. \& Sabah E., 2008. Geological and technical characterisation of Iscehisar (Afyon-Turkey) marble deposits and the impact of marble waste on environmental pollution. Journal of Environmental Management, April 87 (1), 106-116.

Zorlu K., Tunusluoglu M.C. \& Gorum T. et al., 2011. Landform effect on rockfall and hazard mapping in Cappadocia (Turkey). Environmental Earth Sciences, 62, 1685-1693. 